\title{
The Muslim Veil in North America: Issues and Debates
}

Sajida Alvi, Homa Hoodfar, and Sheila McDonough, eds. Toronto: Women's Press, 2003. 306 pages.

When it comes to Muslims in the West, nothing is a more sensational visual symbol than the hijab. Due to the current Muslim and non-Muslim fixation on it, scholarly examination of hijab and related issues is necessary. The Muslim Veil in North America examines some of its historical, sociological/anthropological, and theological aspects. Part 1 engages with the veil's hyper-visibility in Canada. Since the book does not engage with the American experience, I am not sure why the title refers to North America. I enjoyed part 2 immensely, and will use it as a reference on the subject. The bulk of this section explores the historical development of the veil's theological status and nature. This book is different from, say, Maudoodi's Purdah, which sees the veil in its contemporary form as a product of historical processes.

This book is dedicated to diasporic Muslim women, although introductory material in various chapters addresses readers unfamiliar with 
Islam. Undergraduates will appreciate its accessibility in comparison to most academic texts, and it will make the subject comprehensible to lay readers. Unfortunately, this means that the book wavers between being an academic (education, anthropology, and sociology) and a lay read. This is not because the entire book is tailored to different kinds of readers, but because its two parts are rather disjointed. Part 1 addresses a more lay and introductory social science-related reader with basic information; part 2, on the other hand, is a highly specialized examination of exegetical and hadith history.

The editors, in addressing a gaping void in the literature, possibly attempt to do too much: specialized theology, history, politics, anthropology, and sampling of "voices." I would have preferred it to be more selective. Also, "let the voices speak" is a commendable approach, but after a certain point we should go beyond it. There is also a line between "reportage syndrome," writing without an adequate theoretical framework, and skillful academic writing, which allows contextualized voices to be heard by fellow academics within the social sciences. I would also have preferred that the theology and sociology chapters be connected by common threads.

The book critically examines the veil, commonly accepted as a religious obligation, although certain chapters show how the veil, as well as its removal, can serve as empowering strategies. Beyond that, the book does not offer a space where the pro-hijabs might congregate alongside the nohijabs. How can we close the gap between a critical examination of the veil and the average Muslim's notion of veiling as a "mandatory" practice?

In "More than Clothing," Homa Hoodfar uses a research study (how many respondents are involved?) to illustrate that the veil may be empowering for Canadian Muslim women, while Islamophobia is disempowering. In "Coding Dress," Patricia Kelly Spurles shows that that "identity is ... expressed and negotiated, through the ongoing cumulation of statements and practices" at a Muslim school. She frames her essay by exploring the effect of prejudice on Muslims, but this thread seems to trail away. This chapter could certainly be tighter and less fragmented, as much ethnographic data is not clearly framed by the questions (we have superfluous information, such as a paragraph on hijab styles), and remains undeveloped and relatively superficial. Research data from one school is insufficient for Spurles' conclusion that Muslim schools generally offer women a place in community life and a model for participation in other contexts.

In terms of part 1, such fundamental statements as "Muslim women are diverse" and "the veil can be empowering" are important for a lay reader- 
ship. However, it is time to move beyond fundamental statements and ask difficult questions that address the messy aspects of Muslim life in the West.

Reem A. Meshal, in "Banners of Faith and Identities in Construct," examines the results of a survey, showing how Muslim women appear to use the hijab as a banner of faith. Sheila McDonough's "Voices of Muslim Women" gives us seven diverse statements by Canadian women on hijab (why these women?), but offers nothing new beyond presenting a sample of Muslim women's opinions, which, however, is important "basic" reading for a non-Muslim readership.

In "Perceptions of the Hijab in Canada," McDonough traces the historical, social, and policy outlines of non-Muslim perceptions of the hijab in Canada. In the interest of accuracy, Kinnaird College, Lahore, which McDonough describes in a rambling introduction as "a Muslim women's university" is, in fact, a (nationalized) Presbyterian missionary college (not university) that caters to Pakistani Muslim and non-Muslim women.

Part 2 revisits the exegetical literature on veiling. In "Muslim Women and Islamic Religious Tradition," Sajida Sultana Alvi provides a basic historical background to Islam and Muslim women, but focuses almost entirely on the positive side of Muslim history. In "Women's Modesty in Qur'anic Commentaries," Soraya Hajjaji-Jarrah masterfully demonstrates how particular social contexts influenced early commentators to increase exegetical emphasis on women's seclusion and veil. Lynda Clarke's extensive (actually too long) essay, "Hijab According to the Hadith" examines the lack of emphasis on women's covering, hair, and 'awrah in the hadith, comparing this with the excess of emphasis on the veil in later times. This chapter diverges somewhat from most of the others in addressing itself to a more scholarly readership rooted in hadith studies, to the extent that it at times seems a trifle opaque and digressive in its detail.

This book offers a nuanced and critical perspective on the veil for nonMuslim as well as Muslim readers. It goes beyond the mere apologetics or polemics of the kind advanced by non-Muslims or Muslims using the veil as a club with which to beat Islam or Muslim women respectively. The book has a bibliography of 17 pages, an introduction by all 3 editors, and notes on contributors.

Shabana Mir

Ph.D. Candidate, Education Policy Studies,

Indiana University

Bloomington, Indiana 